\title{
Fetal sex influence in the productive performance of dairy cows
}

\section{Influência do sexo do bezerro no desempenho produtivo de vacas leiteiras}

\author{
Anielly de Paula Freitas ${ }^{1 *}$; Manuela Pires Monteiro da Gama²; \\ Guilherme Felipe Ferreira dos Santos ${ }^{1}$; Gabriela Geraldi Mendonça ${ }^{3}$; \\ Mariana Alencar Pereira ${ }^{4}$; Aníbal Eugênio Vercesi Filho ${ }^{5}$; \\ Claudia Cristina Paro de Paz ${ }^{6}$, Lenira El Faro Zadra ${ }^{6}$
}

\begin{abstract}
Investigating factors that could affect milk production of cows is an important way to improve the efficiency of production systems. The purpose of this study was to verify and quantify the influence of calf sex on milk production and lactation length in herds of Holstein, Gir, and Guzera cows. Data from 10,780 lactations of 4,807 Holstein cows that calved between 2001 and 2013; 18,898 lactations of 13,172 Gir cows that calved between 1985 and 2013; and 5,277 lactations of 3,972 Guzera cows that calved between 1987 and 2013 were used. Both the accumulated 305-day milk yield (P305) and the length of the lactation period up to 305 days (DL305) were evaluated. Analysis of variance was performed by the least squares method using the GLM procedure in the SAS statistical program. The P305 was not influenced by the sex of the calf in the Holstein breed. However in the zebu breeds (Gir and Guzera), both P305 and DL305 were significantly affected $(\mathrm{P}<0.01)$ by the sex of the calf, with higher production and average length of lactation in cows that calved males. In addition, a significant difference was also nested within sex of calf and age at first calving $(\mathrm{P}<0.05)$ in the Gir breed. The results indicate that for the zebu breeds, calf sex influences production characteristics.
\end{abstract}

Key words: Milk production. Lactation. Lactation length.

\section{Resumo}

A investigação de fatores que interferem na produção de vacas leiteiras é de grande importância para eficiência dos sistemas de produção. O objetivo do trabalho foi verificar e quantificar a influência do sexo do bezerro sobre produção de leite e sobre a duração da lactação em rebanhos das raças Holandesa, Gir Leiteiro e Guzerá. Foram avaliadas 10.780 lactações de 4.807 vacas Holandesas, paridas entre 2001 e 2013; 18.898 lactações de 13.172 vacas Gir Leiteiro paridas de 1985 a 2013 e 5.277 lactações

\footnotetext{
${ }^{1}$ Discentes do Instituto de Zootecnia, IZ/APTA, Centro APTA Bovinos de Corte, Sertãozinho, SP, Brasil. E-mail: aniellypf@ hotmail.com; santosgfvet@gmail.com

${ }^{2}$ Discente, Faculdade de Medicina de Ribeirão Preto, FMRP/USP, Ribeirão Preto, SP, Brasil. E-mail: manugama@gmail.com

3 Bolsista de Treinamento Técnico FAPESP, Instituto de Zootecnia, IZ/APTA, Centro APTA Bovinos de Corte, Sertãozinho, SP, Brasil. E-mail: gabigeraldi@hotmail.com

${ }^{4}$ Pesquisadora da ABCZ, Associação Brasileira de Criadores de Zebu, ABCZ, Uberaba, MG, Brasil. E-mail: marianaalencar@ abcz.org.br

${ }^{5}$ Pesquisador do Instituto de Zootecnia, IZ/APTA, Centro APTA Bovinos de Leite, Nova Odessa, SP, Brasil. E-mail: anibal@iz.sp. gov.br

${ }^{6}$ Pesquisadoras do Instituto de Zootecnia, IZ/APTA, Centro APTA Bovinos de Corte, Sertãozinho, SP, Brasil. E-mail: claudiapaz@ iz.sp.gov.br; lenira@iz.sp.gov.br

* Auttor for correspondence
} 
ocorridas entre 1987 e 2013, de 3.972 vacas Guzerá. As características estudadas foram produção de leite acumulada em 305 dias e duração da lactação (até 305 dias). A análise de variância foi realizada pelo método de quadrados mínimos, através do procedimento GLM do programa estatístico SAS. A produção de leite acumulada aos 305 dias (P305) na raça Holandesa não foi influenciada pelo sexo do bezerro. Entretanto, para os animais de origem zebuína (Gir leiteiro e Guzerá), ambas as características foram significativamente influenciadas $(\mathrm{P}<0,01)$ pelo sexo do bezerro, sendo observadas maiores produções de leite e duração de lactação para vacas que pariram machos. Também foi observada diferença significativa do sexo do bezerro aninhado dentro de idade da vaca ao parto $(\mathrm{P}<0,05)$ para a raça Gir leiteiro. Estes resultados indicam que para as raças zebuínas, o sexo do bezerro influenciou as características de produção.

Palavras-chave: Produção de leite. Lactação. Duração da lactação.

\section{Introduction}

Purebred and crossbred Holsteins from mild climates are frequently used in production systems in Brazil, and for many years, this breed has undergone selection to increase its productivity. Among the zebu breeds, the Gir and Guzera are most commonly utilized in Brazil and have also undergone selection processes focused on milk production.

In dairy farming, theperformance oflactating cows is directly related to the efficiency of the production system itself. Thus, studies have investigated various factors that influence productivity indices, such as genetic and environmental factors and their interactions, given the differences between different breeds and among herds.

In the past few years, significant effort has gone into analyzing the influence of the sex of the fetus on lactation in humans, monkeys, deer, rodents, marsupials, and cattle (HINDE et al., 2014). The influence of calf sex on milk production in cows has been a particular focus of research; however, the results have been controversial.

Various hypotheses have been proposed, one of which refers to the variation in fetal and placental hormone production according to the sex of the calf, and its influence on cell growth in the mammary gland (HINDE et al., 2014). The genotype of the calf, and its resulting temperament and conduct, can also influence milk production (RICHARDSON et al., 1977) since the more a calf nurses, the more it stimulates milk production in its mother (RIBEIRO et al., 1991).

Taking these studies into consideration, several issues have arisen; e.g., whether the sex of the calf influences milk production (OLIVEIRA et al., 2007). The study of this influence on domestic [Brazilian] herds could have important implications on the management and selection guidelines for these animals. Environmental factors can interfere and mask this influence, and there are significant differences in environmental conditions between the countries where the other studies were conducted and Brazil.

The aim of this study was to determine the existence of the influence of calf sex on milk production in Holstein herds and its quantification, and on milk production and duration of lactation in the Gir and Guzera breeds.

\section{Materials and Methods}

Data from three specialized dairy breeds were used in this study. For the Holstein breed, data were collected on 10,780 births to 4,807 cows between April 2001 and October 2013, along with the sum of their lactations. The study was conducted at Fazenda Santa Rita - Agrindus de Descalvado in the State of São Paulo, Brazil. To assess the production variable of accumulated milk in 305 days (P305) in Holsteins, a linear model was constructed with constants being contemporary groups (CG), sex of calf, milking yield, and order of birth. The duration 
of lactation was regarded as a linear covariate in the model. The contemporary groups were defined by concatenating the year and the month that the cows gave birth, and were constrained by a minimum of five observations per $\mathrm{CG}$.

For the Gir breed, data from 18,898 deliveries by 13,172 cows between 1985 and 2013 were evaluated. For Guzera, data were analyzed from 5,277 deliveries by 3,972 cows between 1987 and 2013. The data from both zebu breeds were acquired from the Brazilian Association of Zebu Breeders (ABCZ). The variables, P305 and duration of lactation up to 305 days (DL305), were evaluated using a linear model with the following constants: sex of calf, contemporary group (herd, year, and season of delivery), and effect of the linear and quadratic regression of P305 and DL305 over the age of the cow at the time of delivery, nested in calf sex. Physiological maturity was regarded as the point at which each breed reached peak production.

In all analyses, we used the least squares method using the GLM procedure in SAS (SAS, 1999). The estimated means of milk production and DL for the sex of the calf were compared using a Tukey's test and were considered to be significant at $\mathrm{P}<0.05$.

\section{Results and Discussion}

The mean P305 observed in the Holstein herd was $10,067.2 \mathrm{~kg}$. In Gir, the mean P305 was 3,386.8 $\mathrm{kg}$ (Table 1), which is higher than the $2,846.95 \mathrm{~kg}$ reported by Prata et al. (2014) for this breed. In Guzera, the observed mean was $2,046.5 \mathrm{~kg}$, which is lower than the mean production of $2,170.24 \mathrm{~kg}$ per lactation reported by Herrera et al. (2008).

Table 1 Data studied and analysis of variance for P305 and DL305 in the Holstein, Gir, and Guzera breeds.

\begin{tabular}{lccccc}
\hline \multirow{2}{*}{ Characteristics } & Holstein & \multicolumn{2}{c}{ Gir } & \multicolumn{2}{c}{ Guzera } \\
\cline { 2 - 5 } & P305 (kg) & P305 (kg) & DL305 (days) & P305 (kg) & DL305 (days) \\
\hline VC (\%) & 18.32 & 32.2 & 19.6 & 41.9 & 25.4 \\
N & 10.780 & 18.898 & 18.882 & 5.277 & 5.262 \\
Observed mean & 10067.2 & 3386.8 & 296.4 & 2046.5 & 241.4 \\
Standard deviation & 1844.3 & 1566.3 & 70.9 & 1129.3 & 73.1 \\
\hline Sex & $\mathrm{NS}$ & $* *$ & $* *$ & $* *$ & $* *$ \\
CG & $\mathrm{NS}$ & $* *$ & $* *$ & $* *$ & $* *$ \\
AHC & $\mathrm{NS}$ & $* *$ & $* *$ & $* *$ & $\mathrm{NS}$ \\
$\mathrm{AHC}{ }^{2}$ & $\mathrm{NS}$ & $* *$ & $* *$ & $* *$ & $\mathrm{NS}$ \\
$\mathrm{AHC}$ nested with sex & $\mathrm{NS}$ & $* *$ & $* *$ & $* *$ & $\mathrm{NS}$ \\
$\mathrm{R}^{2}$ & 0.85 & 0.57 & 0.4 & 0.47 & 0.35 \\
\hline
\end{tabular}

** $\mathrm{P}<0.01 ; * \mathrm{P}<0.05 ; \mathrm{NS}=$ not significant; P305 = Milk production at 305 days; DL305 = Duration of lactation for lactations lasting up to 305 days; $\mathrm{CG}=$ Contemporary group; $\mathrm{AHC}=$ age of heifer at calving; $\mathrm{AHC}^{2}=$ linear effect of age of heifer at calving.

The variation coefficient (VC) for P305 in Holsteins was $18.3 \%$, which is lower than the $29.9 \%$ reported by Ferreira et al. (2003). A possible explanation for the lower estimated VC could be the use of production data from a single herd. On the other hand, the VC for Gir was $32.2 \%$, which is lower than the $45.71 \%$ reported by Gama et al. (2013). The P305 VC for Guzera was 41.9\%, which is higher than that found by Cruz et al. (2009) for 275 -day milk production. The variation coefficient indicates variation relative to mean production, and one potential explanation for the high values found 
is the absence of production uniformity among the herds studied, given that they came from different farms.

The estimated P305 means for the Holstein herd were 9,800.79 $\mathrm{kg}$ and 9,802.95 kg for cows that gave birth to males and females, respectively, with no significant difference in accumulated milk production based on the sex of the calf (Table 1). A study on Holsteins by Hinde et al. (2014) reported higher milk production among cows that calved females and influence of the sex of the fetus not only on lactation after delivery but also on milk production in subsequent lactations. In other words, heifers that gave birth to female calves (Gestation 1) had higher milk production than did those that calved males, and milk production following the birth of their next calf (Gestation 2) was influenced by the sex of the calf from the previous gestation, since lactation and gestation overlap. Physiological factors inherent to gestation and lactation can interfere with milk production when a cow is carrying a female calf, including the average weight at birth and possible association with dystocia as well as the presence of fetal hormones that influence the functioning of the mammary gland via maternal circulation (HINDE et al., 2014). However, environmental factors, such as the use of drugs to stimulate milk production, can mask the effect of the offspring's sex. The number of animals studied from a single property alone may not have been sufficient to identify this effect.

Significant differences for the effect of calf sex $(\mathrm{P}<0.01)$ were observed in the Gir and Guzera herds. Heifers that calved males produced more milk than those that calved females did. In Gir, the estimated P305 means for heifers that calved males and females were 3,565.6 and 3,492.3 $\mathrm{kg}$ of milk, respectively. In Guzera, the estimated means for milk production in cows that calved males and females were $2,075.86 \mathrm{~kg}$ and $1,982.22 \mathrm{~kg}$, respectively.

Previous studies have shown no effect of calf sex on milk production (ESPASANDIN et al.,
2001); higher production in cows nursing females (RODRIGUES, 2012; HINDE et al., 2014), in cows nursing males (RESTLE et al., 2003), and in cows nursing heavier calves, regardless of sex (RUTLEDGE et al., 1971; ROBISON et al., 1978; PIMENTEL et al., 2006); and yearly alternation between the sexes. JEFFERY et al. (1971) demonstrated an interaction between the year and the sex of the calf in terms of milk production, with a greater yield in heifers that calved females. However, upon analyzing the same herd's production the following year, they determined that milk production of cows that calved males was higher than those that calved females. These studies demonstrate the lack of agreement on the effect of sex of offspring on milk production.

Mendonça et al. (2002) concluded that the weight of a calf at birth has a greater influence on the amount of milk produced than its sex does, given that heavier calves consume a larger quantity of milk and are responsible for greater production of placental hormones related to lactation, which consequently increase the stimulus to produce milk. However, we could not substantiate this hypothesis given the lack of recorded calf weights in the data archive used in this study.

The age of the heifer at the time of calving is one of the main factors affecting milk production and significantly influences $\mathrm{P} 305(\mathrm{P}<0.01)$ (TEODORO et al., 2000; RESTLE et al., 2003; RANGEL et al., 2009). A greater degree of physiological maturity, which is related to the development of the mammary gland (REECE, 2007) and also to body size, results in higher milk production due to the greater capability for food intake (RAIDAN et al., 2015).

In the present study, we noted that Gir cows reach physiological maturity at the age of 104 months (Figure 1), which is higher than the number reported by Martinez et al. (1992), which is between 93 and 98 months of age. The Brazilian Association of Gir Breeders (ABCGIL) uses 93 months as the benchmark for physiological maturity in its genetic 
upgrading program. Thus, the mean age at which Gir cattle reached physiological maturity in this study was higher than the age used in genetic upgrading programs for the breed. Physiological maturity in the Guzera breed for P305 occurred between 94 and 104 months (Figure 2), corroborating findings by Rangel et al. (2009), who suggested that milk production was highest in heifers at their fifth calving, and by Theodore et al. (2000), who found that milk production peaked around 100 months of age.

Figure 1. Regression for milk production over sex of calf nested in age of heifer at calving in Gir cattle.

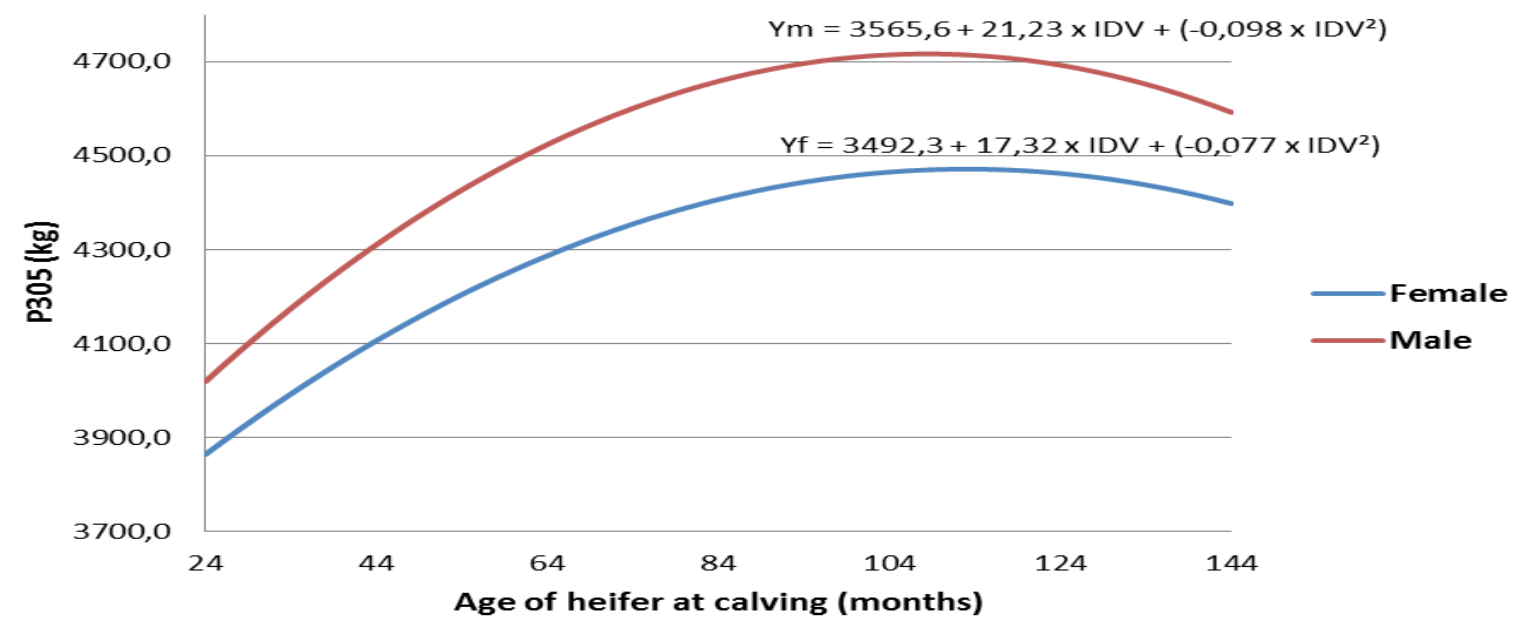

Figure 2. Regression for milk production over sex of calf nested in age of heifer at calving in Guzera cattle.

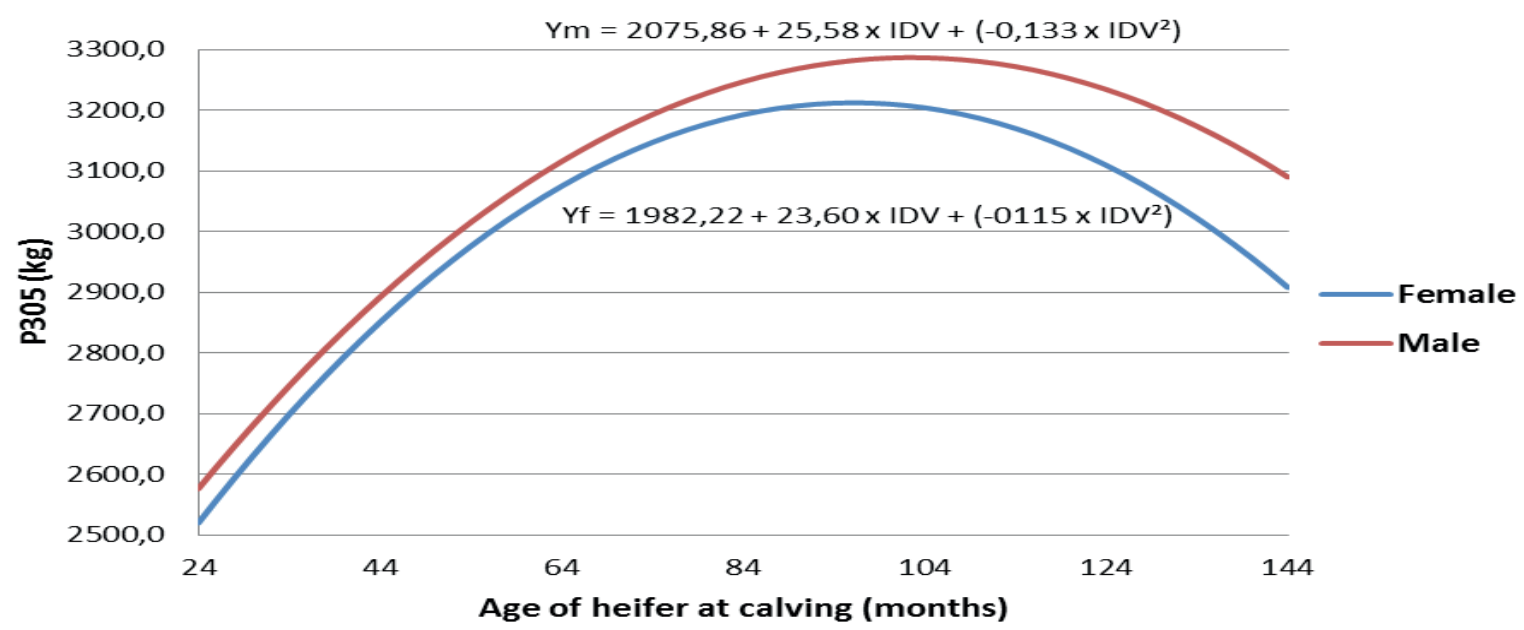

The effect of calf sex nested in the cow's age at calving was examined in both zebu breeds, and a significant difference between the trends was noted $(\mathrm{P}<0.05)$. In Gir, the estimated regression coefficients for heifer age at calving described a quadratic relation with a peak in production occurring at 104 months of age (Figure 1), and in Guzera, the estimated regression coefficients for heifer age at calving showed a peak in production between 94 and 104 months of age (Figure 2). Cows that gave birth to females reached physiological maturity slightly sooner than those that gave birth to males. 
Figures 1 and 2 demonstrate the distinguishing features of milk production of cows calving males and females, nested in the cow's age at calving, which has the clearest effect in Gir. The difference between milk production of cows that calved males and females remained practically constant as the cow's age at calving increased. However, for Guzera, the difference in milk production according to sex was more pronounced as the cow approached physiological maturity.

For the DL305 variable, significant differences in the effect of sex of calf $(\mathrm{P}<0.01)$ were observed in Gir and Guzera herds. Heifers that calved males had longer-lasting lactations than those that calved females did, in contrast to the results obtained by Santos et al. (1990) and Barbosa et al. (1997), who did not find any difference between the sexes in the duration of lactation.

In Gir, the mean DLs for heifers that calved males and females were 302.4 days and 298.1 days, respectively. The mean observed for the Gir herd (296.4 days) was greater than the means reported by Herrera et al. (2008) and Prata et al. (2014) for the same breed. The estimated mean DL in Guzera was 244.2 days for cows that calved males and 237.1 days for cows that calved females, and the mean observed for the herd (241.4 days) was lower than that found by Verneque et al. (2008) and by Rangel et al. (2009).

The DL was influenced by the age of the cow at calving only in Gir $(\mathrm{P}<0.01)$ (Table 1). The effect of the calf's sex nested in the cow's age at calving $(\mathrm{P}>0.01)$ was also significant in Gir (Figure 3). The trend for cows that calved males was practically linear, with declining duration of lactation up to 144 months. The trend for cows that calved females showed a sharper curve, with minimum lactation durations observed at 114 months, after which the duration increased again. Younger cows showed longer lactation durations than older cows did. This is due to the fact that the longest duration seen in the first lactation is related to the longest period of service, since these animals are still growing and need to allocate nutrients for their development, milk production, and potential reproduction. Similar results were found by Glória et al. (2006) with Holstein-Gir crossbreeds.

Figure 3. Regression for duration of lactation over sex of calf nested in age of heifer at calving in Gir cattle.

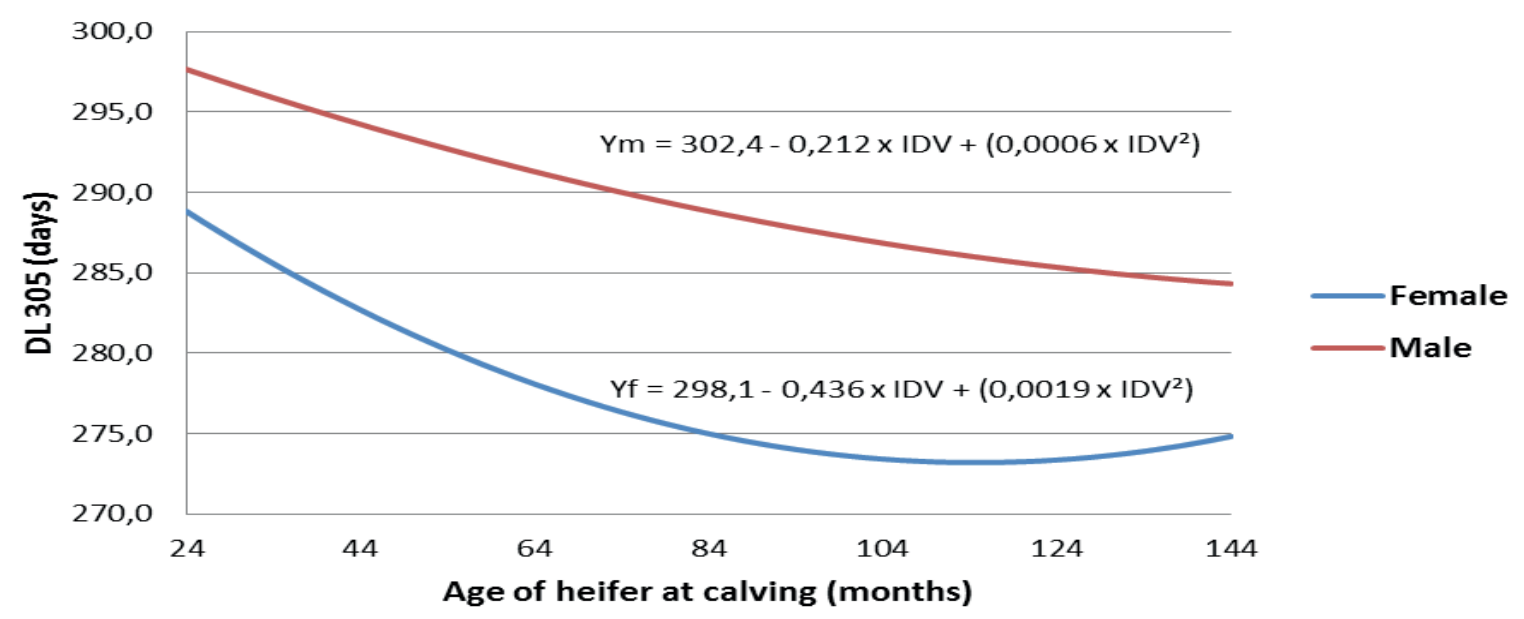

Holsteins did not demonstrate any significant effect of calf sex on milk production, whereas in the Gir and Guzera breeds, the effect of sex of calf on milk production and lactation was significant. 
This result can be explained by the breeds' background. Holsteins have been bred for milk production for centuries and do not require the presence of a calf to yield milk, since calves are separated from their mothers shortly after birth. In contrast, the Gir and Guzera zebu breeds served a dual function when they were introduced to Brazil, being primarily raised as beef cattle (CRUZ, 2014; FERNANDES, 2015). Since genetic selection for increased production of milk and its constituents took place only a few decades ago, the presence of a calf is still required for milk production.

\section{Conclusions}

In the Holstein herd studied, no significant difference was observed in accumulated milk production at 305 days relative to the calving of males and females.

However, in both the zebu breeds studied, the sex of the calf affected both the production of milk at 305 days and the duration of lactation.

The fact that zebu calves stay with their mothers until the end of lactation may explain the difference in results between taurine and zebu cattle, since the demand of male calves, which are generally larger, can increase stimulation, resulting in increased milk production by their mothers.

\section{Acknowledgements}

The Agrindus Farm, the Brazilian Zebu Breeders Association (ABCZ), the São Paulo Research Foundation (FAPESP) by the technical training scholarship, the Coordination for the Qualification of Higher Level Staff in Brazil (CAPES) for the master's scholarship and the National Counsel of Technological and Scientific Development (CNPq) for productivity fellowships and doctoral scholarship.

\section{References}

BARBOSA, P. F.; COSTA, J. L. da; RODRIGUES, A. D. A.; BARBOSA, R. Causas da variação da produção de leite e duração da lactação em um rebanho da Raça Holandesa na região de São Carlos, SP. In: EMBRAPA PECUÁRIA SUDESTE-ARTIGO EM ANAIS DE CONGRESSO (ALICE). In: REUNIÃO ANUAL DA SOCIEDADE BRASILEIRA DE ZOOTECNIA, 34., 1997, Juiz de Fora. Anais... Juiz de Fora: SBZ, 1997. p. 103-105.

CRUZ, D. A. C. Estudo do padrão de curvas de lactação de animais da raça guzerá empregando-se modelos de regressão aleatória. 2014. Dissertação (Mestrado em Produção Animal Sustentável) - Instituto de Zootecnia, Nova Odessa.

CRUZ, G. R. B.; RIBEIRO, M. N.; PIMENTA FILHO, E. C. Estimativas de parâmetros de curvas de lactação de bovinos. Archivos de Zootecnia, Córdoba, v. 58, n. 224, p. 695-704, 2009.

ESPASANDIN, A. C.; PACKER, I. U.; ALENCAR, M. D. Produção de leite e comportamento de amamentação em cinco sistemas de produção de gado de corte. Revista Brasileira de Zootecnia, Viçosa, MG, v. 30, n. 3, p. 702708, 2001.

FERNANDES, A. R. Associação entre a produção de leite e as características de úbere e de manejo no melhoramento genético do Gir Leiteiro. 2015. Dissertação (Mestrado em Sanidade e Produção Animal nos Trópicos) - Universidade de Uberaba, Uberaba.

FERREIRA, W. J.; TEIXEIRA, N. M.; EUCLYDES, R. F.; VERNEQUE, R. D. S.; LOPES, P. S.; TORRES, R. D. A.; WENCESLAU, A. A.; SILVA, M. V. G. B.; MAGALHÃES JÚNIOR, M. N. Avaliação genética de bovinos da raça Holandesa usando a produção de leite no dia do controle. Revista Brasileira de Zootecnia, Viçosa, MG, v. 32, n. 2, p. 295-303, 2003.

GAMA, M. P. M.; PRATA, M. A.; ALBUQUERQUE, L. G.; CAVALLARI, C. H.; ZADRA, L. E. F. Fatores de ajuste da produção de leite para o efeito de idade da vaca ao parto na raça Gir Leiteiro. In: SIMPÓSIO BRASILEIRO DE MELHORAMENTO ANIMAL, 10., 2013, Uberaba - MG. Anais... Uberaba: SBMA, 2013. p. 1-3.

GLÓRIA, J. R.; BERGMANN, J. A.; REIS, R. B.; COELHO, M. S.; SILVA, M. A. Efeito da composição genética e de fatores de meio sobre a produção de leite, a duração da lactação e a produção de leite por dia de intervalo de partos de vacas mestiças Holandês-Gir. Arquivo Brasileiro de Medicina Veterinária e Zootecnia, Belo Horizonte, v. 58, n. 6, p. 1139-1148, 2006. 
HERRERA, L. G. G.; EL FARO, L.; ALBUQUERQUE, L. D.; TONHATI, H.; MACHADO, C. H. C. Parâmetros genéticos para produção de leite no dia do controle e para produção de leite até 305 dias nas primeiras lactações de vacas da raça Gir. Revista Brasileira de Zootecnia, Viçosa, MG, v. 37, n. 10, p. 1774-1780, 2008.

HINDE, K.; CARPENTER, A. J.; CLAY, J. S.; BRADFORD, B. J. Holsteins favor heifers, not bulls: biased milk production programmed during pregnancy as a function of fetal sex. Plos One, San Francisco, v. 9, n. 2, p. e86169, 2014.

JEFFERY, N. B.; BERG, R. T.; HARDIN, R. T. Factors influencing milk yield of beef cattle. Canadian Journal Animal Science, Ottawa, v. 51, n. 3, p. 551-560, 1971.

MARTINEZ, M. L.; COSTA, C. N.; TEIXEIRA, N. M. Mixed model estimation of age-season adjustment factors for milk yield of Gir cattle. Indian Journal of Dairy Science, Champaign, v. 45, n. 11, p. 591-597, 1992.

MENDONÇA, G.; PIMENTEL, M. A.; CARDELLINO, R. A.; OSÓRIO, J. C. S. Produção de leite em primíparas de bovinos Hereford e desenvolvimento ponderal de terneiros cruzas taurinos e zebuínos. Revista Brasileira de Zootecnia, Viçosa, MG, v.31, n. 1, p. 467-474, 2002.

OLIVEIRA, V. C.; FONTES, C. A. A.; SIQUEIRA, J. G. de; FERNANDES, A. M.; SANT'ANA, N. F.; NETO, A. C. Produção de leite e desempenho dos bezerros de vacas Nelore e mestiças. Revista Brasileira de Zootecnia, Viçosa, MG, v. 36, n. 6, p. 2074-2081, 2007.

PIMENTEL, M. A.; MORAES, J. C. F.; JAUME, C. M.; LEMES, J. S.; BRAUNER, C. C. Lactation performance of Hereford cows raised in a range system in the state of Rio Grande do Sul. Revista Brasileira de Zootecnia, Viçosa, MG, v. 35, n. 1, p. 159-168, 2006.

PRATA, M. A.; PEREIRA, M. C.; EL FARO, L.; CARDOSO, V.L.; VERCESI FILHO,A.E.; VERNEQUE, R. D. S.; BRUNELI, F. Â. T.; PEIXOTO, C. D. Efeito do intervalo de partos sobre a eficiência produtiva e econômica em rebanhos gir leiteiro. Boletim da Indústria animal, Nova Odessa, v. 71, n. 1, p. 1-7, 2014.

RAIDAN, F. S. S.; COSTA, M. D. D.; RUAS, J. R. M.; ROCHA JUNIOR, V. R.; SILVA, E. A. D.; SANTIAGO, R. L.; RIBEIRO, A. M. F.; RIBAS, W. F. G. Desempenho produtivo e reprodutivo de fêmeas F1 Holandês x Nelogir. Revista Brasileira de Saúde e Produção Animal, Salvador, v. 16, n. 3, p. 678-687, 2015.

RANGEL,A.H.N.;GUEDES,P.L.C.;ALBUQUERQUE, R. P. F.; NOVAIS, L. P.; LIMA JUNIOR, D. M. Desempenho produtivo leiteiro de vacas Guzerá. Revista Verde de Agroecologia e Desenvolvimento Sustentável, Mossoró, v. 4, n. 1, p. 85-89, 2009.
REECE, W.O. Dukes, fisiologia dos animais domésticos. 12. ed. Rio de Janeiro: Guanabara Koogan S.A., 2007. $946 \mathrm{p}$.

RESTLE, J.; PACHECO, P. S.; MOLETTA, J. L.; BRONDANI, I. L.; CERDÓTES, L. Grupo genético e nível nutricional pós-parto na produção e composição do leite de vacas de corte. Revista Brasileira de Zootecnia, Viçosa, MG, v. 32, n. 3, p. 585-597, 2003.

RIBEIRO, E. L. A.; RESTLE, J.; PIRES, C. C. Produção e composição do leite em vacas Charolês e Aberdeen Angus amamentando bezerros puros ou mestiços. Pesquisa Agropecuária Brasileira, Brasília, v. 26, n. 8, p. 1267-1273, 1991.

RICHARDSON, F. D.; OLIVER, J.; CLARKE, G. P. Y. Analysis of some factors which affect the productivity of beef cows and their calves in a marginal area of Rhodesia. 2. The yield and composition of milk of suckling cows. Animal Production, Edinburgh, v. 25, n. 4, p. 359-372, 1977.

ROBISON, O. W.; YUSUFF, M. K. M.; DILLARD, E. U. Milk production in Hereford cows I. Means and correlations. Journal of Animal Science, Champaign, v. 47, n. 1, p. 131-135, 1978.

RODRIGUES, P. F. Avaliação da habilidade materna e eficiencia reprodutiva de vacas de corte de diferentes composições raciais. 2012. Dissertação (Mestre em Zootecnia) - Universidade Federal de Pelotas, Pelotas.

RUTLEDGE, J. J.; ROBISON, O. W.; AHLSCHWEDE, W. T.; LEGATES, J. E. Milk yield and its influence on 205-day weight of beef calves. Journal of Animal Science, v. 33, n. 3, p. 563-567, 1971.

SANTOS, E. S.; MIRANDA LEITE, P. R. de; LÔBO, R. B.; DURÃES, M. C. Progresso genético do rebanho Gir Leiteiro de Umbuzeiro, PB. Pesquisa Agropecuária Brasileira, Brasília, v. 25, n. 9, p. 1339-1348, 1990.

STATISTICAL ANALYSIS SYSTEM - SAS. User's Guide, Version 8, Inst., Inc.: Cary, 1999. 295 p.

TEODORO, R. L.; MARTINEZ, M. L.; VERNEQUE, R. S.; PIRES, M. de F. A. Parâmetros genéticos e fatores de ajuste da produção de leite para o efeito de idade da vaca ao parto na raça Guzerá. Revista Brasileira de Zootecnia, Viçosa, MG, v. 29, p. 2248-2252, 2000. Suplemento 2.

VERNEQUE, R. S.; PRATA, M. A.; CARNEIRO, R. V.; TEODORO, R. L.; PENNA, V. M.; PEIXOTO, M. G. C. D. Progresso genético e fenotípico na raça Guzerá sob seleção para leite. In: SIMPÓSIO BRASILEIRO DE MELHORAMENTO ANIMAL, 2008, São Carlos. Anais... São Carlos: SBMA, 2008. 4 p. CD-ROM. 